\title{
Postharvest conservation of 'Avalanche' cut roses with hydroxypropyl methylcellulose-beeswax natural coating
}

\section{Conservação pós-colheita de rosas de corte 'Avalanche' com recobrimento natural a base de hidroxipropil metilcelulose e cera de abelha}

\author{
José Sidnaldo Pinsetta Junior ${ }^{1}$, Claudia Fabrino Machado Mattiuz ${ }^{2}$ \\ Emmanuel Moreira Pereira ${ }^{1} \mathbb{D}$, Ben-Hur Mattiuz ${ }^{1 *} \mathbb{D}$
}

\author{
1Universidade Estadual Paulista/UNESP, Faculdade de Ciências Agrárias e Veterinárias, Jaboticabal, SP, Brasil \\ 2Universidade de São Paulo/USP, Escola Superior de Agricultura "Luiz de Queiroz"/ESALQ, Piracicaba, SP, Brasil \\ *Corresponding author: b.mattiuz@unesp.br \\ Received in March 18, 2019 and approved in August 21, 2019
}

\begin{abstract}
The use of postharvest coatings of fruits and vegetables has been the subject of many studies for their ability to extend the shelf life of vegetables. However, little is known about the effect of coatings on postharvest of cut flowers. We evaluated the effect of different concentrations of natural coating based on hydroxypropyl methylcellulose (HPMC) and beeswax (CA) on postharvest of cut roses. White rose cultivar 'Avalanche' obtained from commercial production at the bud stage were used. The coating was prepared by the combination of the hydrophilic phase (HPMC) and the lipid phase (CA) suspended in water, resulting in $50 \mathrm{~g}$ lipids / $100 \mathrm{~g}$ emulsion. The emulsion was sprayed on the flowers in different volumes: 0 (distilled water); $1.5 ; 3.0$ and $4.5 \mathrm{~mL}$ rose ${ }^{-1}$. The roses were maintained at $20 \pm 1{ }^{\circ} \mathrm{C}$ and $\mathrm{RH}>70 \%$ for 9 days for physiological analysis and 12 days for vase life. Data were collected every 3 days for accumulated of fresh mass, water absorption, relative water content (RWC), membrane stability index (MSI) and vase life. The application of $3.0 \mathrm{~mL} / \mathrm{rose}$ of the coating resulted in higher RWC and MSI throughout the storage time. We conclude that the use of a natural coating of HPMC/beeswax sprayed at $3.0 \mathrm{~mL} /$ rose increased the vase life of the 'Avalanche' rose by 2 days.
\end{abstract}

Index terms: HPMC; Rosa sp.; vase life.

\begin{abstract}
RESUMO
O uso de recobrimentos na pós-colheita de frutas e hortaliças é objeto de estudos há vários anos pela sua capacidade de prolongar a vida de prateleira de vegetais. No entanto, pouco se sabe acerca do uso destes recobrimentos na conservação pós-colheita de flores de corte. $\mathrm{O}$ objetivo deste trabalho foi avaliar o efeito de diferentes concentrações de recobrimento natural a base de Hidroxipropilmetilcelulose (HPMC) e cera de abelha (CA) na conservação pós-colheita de rosas de corte. Foram utilizadas rosas brancas da cultivar 'Avalanche' provenientes de área de produção comercial. As rosas foram colhidas no estádio de botão, correspondente ao ponto de colheita utilizado para comercialização. O recobrimento foi preparado pela combinação da fase hidrofílica (HPMC) e da fase lipídica (CA) suspensas em água, resultando em $50 \mathrm{~g}$ de lipídios/100g de emulsão. A emulsão foi aplicada na flor por pulverização em diferentes volumes: 0 (água destilada); 1,$5 ; 3,0$ e 4,5 mL rosaำ, considerados os tratamentos. As rosas foram mantidas a $20 \pm 1^{\circ} \mathrm{C}$ e UR $>70 \%$ durante 9 dias para as análises fisiológica e 12 dias para a vida de vaso. A cada 3 dias foram avaliadas porcentagem acumulada de massa fresca, porcentagem de absorção de água, conteúdo relativo de água (CRA), índice de estabilidade da membrana (IEM) e vida de vaso. A aplicação do recobrimento a 3,0 mL/rosa resultou em maior CRA e IEM ao longo do tempo de armazenamento. Os resultados permitiram concluir que o uso de um recobrimento natural à base de HPMC e cera de abelha aplicado por pulverização a 3,0 mL/rosa aumentou a vida de vaso de rosas 'Avalanche' em 2 dias.
\end{abstract}

Termos para indexação: HPMC; Rosa sp.; vase life.

\section{INTRODUCTION}

Quality and floral longevity are economically important factors for the commercialization of cut flowers due to the short postharvest life of many species.

The rose is the most important cut flower in world sales. In the year 2017, 935 tons of roses were marketed in the main vegetable-trading warehouse in Brazil (CEAGESP, 2019).

Cutting roses are particularly vulnerable to water stress during postharvest handling, and their ornamental value is often reduced during marketing because of their rapid dehydration (Doi et al., 2000; van Doorn; Reid, 1995). Regulation of water loss is mainly under 
physiological control, whereas water absorption is a physical process in cut flowers (Fanourakis et al., 2012).

The water relations of cut flowers are dependent on a series of physiological and anatomical characteristics regulating rates of water loss and water absorption. These characteristics are the result of the complex interaction between the genotype and the environment during cultivation, and subsequently determine the vase life of a particular cut flower (Fanourakis et al., 2012).

In roses, the symptoms of senescence related to water stress are the wilting of flowers and leaves, followed by the curvature of the floral peduncle (Torre; Fjeld; Gislerød, 2001; Mortensen; Gislerød, 2005). Senescence is the main reason for short vase life and low quality of cut flowers (Mansouri, 2012; Saeed et al., 2016), which is associated with structural modifications, increased lipid peroxidation and membrane extravasation, increased respiratory rate, elevation of hydrolytic enzyme activity, changes in various cellular organelles and degradation of molecules (Mansouri, 2012; Rani; Singh, 2014). Nowak and Rudnick (1990) report that cut flowers are very susceptible to water loss, and that when they lose 10-15\% of their fresh mass, they are usually wilted.

Postharvest treatments with the use of coatings constitute an important tool for maintaining floral quality. When applied to the surface of the plant, it changes their physical properties and helps reduce water loss by modifying gas exchange, which in the case of cut flowers may increase vase life. Also, it is easy to use and apply.

The hydroxypropyl methylcellulose compound (HPMC) is a water-soluble cellulose hydrocolloid with good film-forming properties (Sanderson, 1981). Cellulose derivative coatings (HPMC) are formulated specifically to reduce $\mathrm{O}_{2}$ and $\mathrm{CO}_{2}$ exchanges, retarding fruit ripening (McGuire; Hallman, 1995). Lipid-based coatings are generally used to produce moisture barrier. Among the lipid materials, beeswax is used to improve the water vapor barrier characteristics (Fagundes et al., 2013). The use of a coating that associates the characteristics of a material with a barrier to gas exchange, and another with a barrier to humidity, can potentially extend the vase life in cut flowers.

Research has shown that HPMC-based coatings (associated with other substances) extend the postharvest life of plums (Navarro-Tarazaga; Massa; Pérez-Gago, 2011), mandarins (Pérez-Gago; Rojas; Del Rio, 2002) and cherry tomatoes (Fagundes et al., 2014). However, no studies on the effects of coatings with HPMC and beeswax on flower postharvest were found.
We hypothesize that the partial blockage of rose petal transpiration by the coating prolongs vase life and modificates water relations. Thus, the present research studied the effect of different concentrations of a natural coating based on HPMC and beeswax on cut roses of cv. 'Avalanche'.

\section{MATERIAL AND METHODS}

\section{Materials}

White roses of the 'Avalanche' cultivar were obtained directly from commercial growers in the city of Holambra (22 $37^{\prime} 59^{\prime \prime} \mathrm{S} ; 47^{\circ} 03^{\prime} 20^{\prime \prime} \mathrm{W}$ ), São Paulo state, Brazil. The roses were harvested at the bud stage (commercialization point) and transported to the laboratory in $3 \mathrm{~h}$; treatments were applied on the same day. In the laboratory, stems were standardized to $40 \mathrm{~cm}$ by cutting the stems into containers with distilled water.

Hydroxypropyl methylcellulose polysaccharide (HPMC - Methocel E1 $5^{\circledR}$ ) was obtained from Dow Chemical, USA. The beeswax was obtained with Synth. The stearic acid (CAS 57-11-4) and glycerol (CAS 56-81-5) reagents were obtained by Merck KGaA (Darmstadt, DE).

\section{Coating preparation}

The coating was prepared by the combination of the hydrophilic phase (HPMC) and the lipid phase using beeswax (BW), both suspended in water, according to the methodology of Navarro-Tarazaga, Massa and PérezGago, (2011). The HPMC was diluted in distilled water at $90{ }^{\circ} \mathrm{C}$ under constant stirring at a ratio of $5 \mathrm{~g} / 100 \mathrm{~g}$, and cooled to $20^{\circ} \mathrm{C}$ in an ice bath for 30 minutes. Then, BW was added at $50 \mathrm{~g} / 100 \mathrm{~g}$ (dry basis, bs), glycerol (plasticizer function) at HPMC: glycerol $(2: 1, \mathrm{w} / \mathrm{w})$ and stearic acid (emulsifier) at CA: stearic acid $(5: 1, w / w)$. At the end, sufficient distilled water was added to give a solids concentration of $4 \mathrm{~g} / 100 \mathrm{~g}$. All ingredients were mixed and heated to $90^{\circ} \mathrm{C}$ to melt the CA and the emulsion was formed with the aid of a shaker mill for 1 minute at 13000 $\mathrm{rpm}$ followed by 3 minutes at $22000 \mathrm{rpm}$. The emulsion, under agitation for 30 minutes, was cooled in an ice bath to $20^{\circ} \mathrm{C}$, to ensure complete HPMC hydration.

\section{Coating application and assessments}

Treatments consisted of spraying ( $30 \mathrm{psi})$ the emulsion on each rose with a volume of 0 (distilled water), 1.5, 3.0 and $4.5 \mathrm{ml} /$ rose. After application of the treatments, the roses were conditioned in erlenmeyers with $500 \mathrm{~mL}$ of water with $0.33 \mathrm{mg} \mathrm{L}^{-1}$ of active chlorine. 
During the experimental period the roses were kept in a room with a temperature of $20{ }^{\circ} \mathrm{C}$ and $70-80 \%$ U.R.

The experiment was arranged in a completely randomized design, in a factorial composed of two factors: four post-harvest treatments and four evaluation dates $(0,3,6,9$ days). For each combination of factors, four replicates were used, with three flowers each. The experiment was evaluated every 3 days for a total period of 9 days.

The accumulated percentage of fresh mass (FM) was evaluated by weighing three stems of each replicate, totaling 12 stems per treatment.

The percentage of water absorption (WA) was evaluated by measuring the amount of water absorbed from the Erlenmeyer.

The membrane stability index (MSI) was obtained following the methodology of Singh and Kumar (2008). From each rose, five $1 \mathrm{~cm}^{2}$ discs were removed from the petals of the third layer, counted from the base, and held in $5 \mathrm{~mL}$ of deionized water for 3 hours at room temperature. Then, the electrical conductivity of the solution was measured before (value A) and after heating at $100^{\circ} \mathrm{C}$ (value B). The MSI was calculated using the Equation 1:

$\operatorname{MSI}(\%)=[1-($ valor $\mathrm{A}) /($ valor B $)] \times 100$

The relative water content (RWC) of the petals was evaluated using petals from the third layer, counted from the base. Ten $1 \mathrm{~cm}^{2}$ discs were removed, weighed (fresh mass), and immersed in Petri dishes with deionized water for 4 hours at room temperature for complete hydration. The disks were removed from the water, dried with paper towel, again weighed (turgid mass) and placed in a drying oven at $105{ }^{\circ} \mathrm{C}$ for 12 hours. After which time, the disks were placed in a desiccator until they reached room temperature and weighed (dry mass). The RWC was calculated using the Equation 2 by Kramer (1983):

$$
\text { RWC }=\frac{\text { Fresh mass }- \text { Dry mass }}{\text { Turgid mass }- \text { Dry mass }} \times 100
$$

The end of flower longevity (vase life) was considered when they showed petal wilting and/or bent-neck in $50 \%$ of the stems.

The data were submitted to analysis of variance and the averages were compared by the Tukey test at $5 \%$ of probability, using Agrostat software. The interaction treatments were submitted to the regression analysis using the software Prism 6.

\section{RESULTS AND DISCUSSION}

There was a reduction of the fresh mass loss (FML) of the 'Avalanche' roses treated with the HPMC and beeswax-based coatings, especially with $3.0 \mathrm{~mL}$ and $4.5 \mathrm{~mL}$ coating / stem, which had average FML values of $0.19 \%$ and $1.45 \%$, respectively, and did not differ significantly from each other (Table 1).

All coating treatments resulted in a smaller loss of fresh mass. The treatment with $3.0 \mathrm{~mL}$ of coating / stem showed a higher fresh mass gain up to the 3rd day of evaluation, and higher accumulated fresh mass during the period (Figure 1A and Table 1).

The treatment with $3.0 \mathrm{~mL}$ of the coating showed the highest water absorption mean of $4.82 \%$, differing from the control with a mean of $3.62 \%$ (Table 1 ). In relation to the storage time, all treatments had increased water uptake up to the 6th day of evaluation. The treatment with 3.0 $\mathrm{mL}$ of the coating showed the highest water absorption in relation to the other treatments (Figure 1B).

Table 1: Physiological characterization of rose cv. Avalanche roses coated with hydroxypropyl methylcellulose (HPMC) and beeswax (BW) and stored at $20^{\circ} \mathrm{C}$ for 9 days and $70-80 \% \mathrm{RH}$.

\begin{tabular}{ccccc}
\hline Treatment & AFML & RWU & RWC & MSI \\
\hline Control & $-4.15 b^{\star}$ & $3.62 \mathrm{c}$ & $69.91 \mathrm{~d}$ & $64.90 \mathrm{c}$ \\
$1,5 \mathrm{~mL}$ coating & $-3.26 \mathrm{~b}$ & $3.90 \mathrm{bc}$ & $74.39 \mathrm{~b}$ & $66.04 \mathrm{~b}$ \\
$3,0 \mathrm{~mL}$ coating & $-0.19 \mathrm{a}$ & $4.82 \mathrm{a}$ & $78.99 \mathrm{a}$ & $74.76 \mathrm{a}$ \\
$4,5 \mathrm{~mL}$ coating & $-1.45 \mathrm{a}$ & $4.08 \mathrm{~b}$ & $72.44 \mathrm{c}$ & $63.01 \mathrm{~d}$ \\
MSD (5\%) & 1.60 & 0.31 & 1.22 & 1.03 \\
CV (\%) & 13.33 & 11.69 & 1.49 & 1.39 \\
\hline
\end{tabular}

${ }^{*}$ Means followed by the same letter in the columns do not differ by the Tukey test $(P>0,05)$. AFML = accumulated fresh mass loss; $\mathrm{RWU}=$ relative water uptake; RWC = relative water content; $\mathrm{MSI}$ = membrane stability index. Results expressed as percentage (\%). 


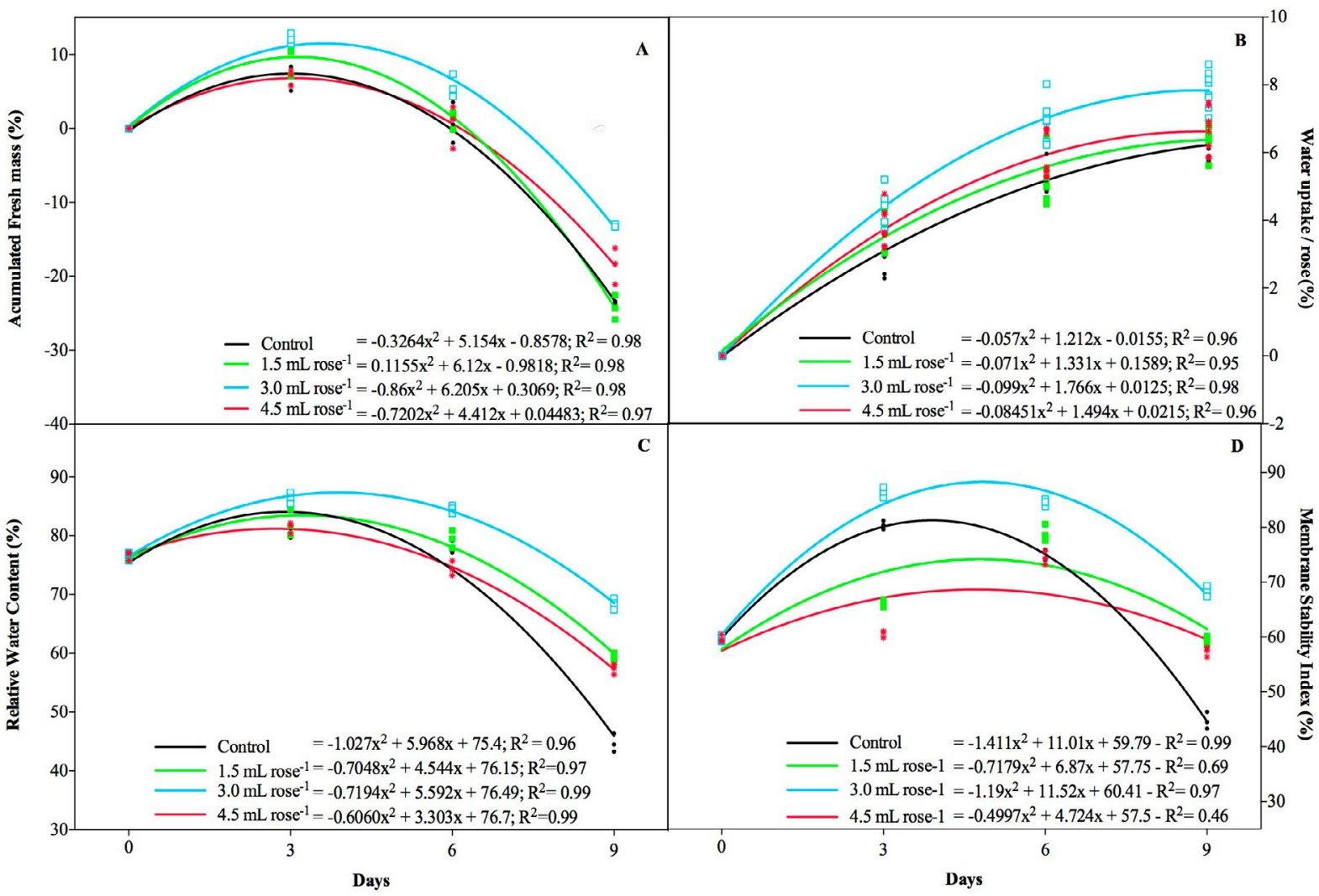

Figure 1: Accumulated fresh mass loss (A), Water uptake (B), Relative water content (C) and Membrane stability index (D) of cut rose cv. Avalanche treated with hydroxypropyl methylcellulose (HPMC)/Beewax (BW)-based coating stored at $20^{\circ} \mathrm{C}$ and $70-80 \% \mathrm{RU}$.

From the 6th day of evaluation, a reduction in water absorption was observed, which may be associated with xylem vessel occlusion, as previously reported (Imsabai et al., 2013; Fanourakis et al., 2012).

The relative water content differences between the treatments, highlighting the $3.0 \mathrm{~mL}$ coating, resulted in a CRA of $78.9 \%$, while the control had a mean of $69.9 \%$ (Table 1). According to Sengupta and Majumder (2009), RWC below $70 \%$ has been considered a critical wilting point for many species used as cut flowers. The treatment with 1.5 $\mathrm{mL}$ of the coating produced the second best RWC of $74.9 \%$.

RWC increased up to the 3rd day of storage, which corroborates with the results of fresh mass accumulation (Figure 1A). From the 6th day of storage, the RWC of control roses decreased much more than other treatments. The 1.5 and $3.0 \mathrm{~mL}$ treatments maintained the RWC at a level equal to or greater than the initial one, indicating an adequate vegetable water status (Figure 1C).

Treatment with $3.0 \mathrm{~mL}$ coating had the highest MSI (74.7\%), followed by $1.5 \mathrm{~mL}(66.0 \%)$. The control differed from the 3.0 and $1.5 \mathrm{~mL}$ treatments, showing a MSI of $64.9 \%$ (Table 1). The MSI increased up to the 3rd day of storage for all treatments. The $3.0 \mathrm{~mL}$ treatment had the highest MSI over the whole period. The control showed a tendency of membrane instability from day 3 of storage (Figure 1D).

Treatment with $3.0 \mathrm{~mL}$ coating produced the higher MSI, which can be attributed to better maintenance of the water status of the stems, avoiding an increase in stress enzymes, related to lipid peroxidation, thus contributing to higher membrane stability.

$3.0 \mathrm{~mL}$ coating extended vase life up to 12 days, while the other treatments lasted up to 10 days (Figure 2 and 3 ).

The results of $4.5 \mathrm{~mL}$ coating can be explained by the thicker layer formed over the petals resulting in osmotic dehydration, where water flows from the petal to the coating, justified by the lower RWC and MSI compared to $3.0 \mathrm{~mL}$ treatment. Dehghannya et al. (2010) observed a higher osmotic dehydration in apple slices using coating based on carboxy-methil cellulose. 


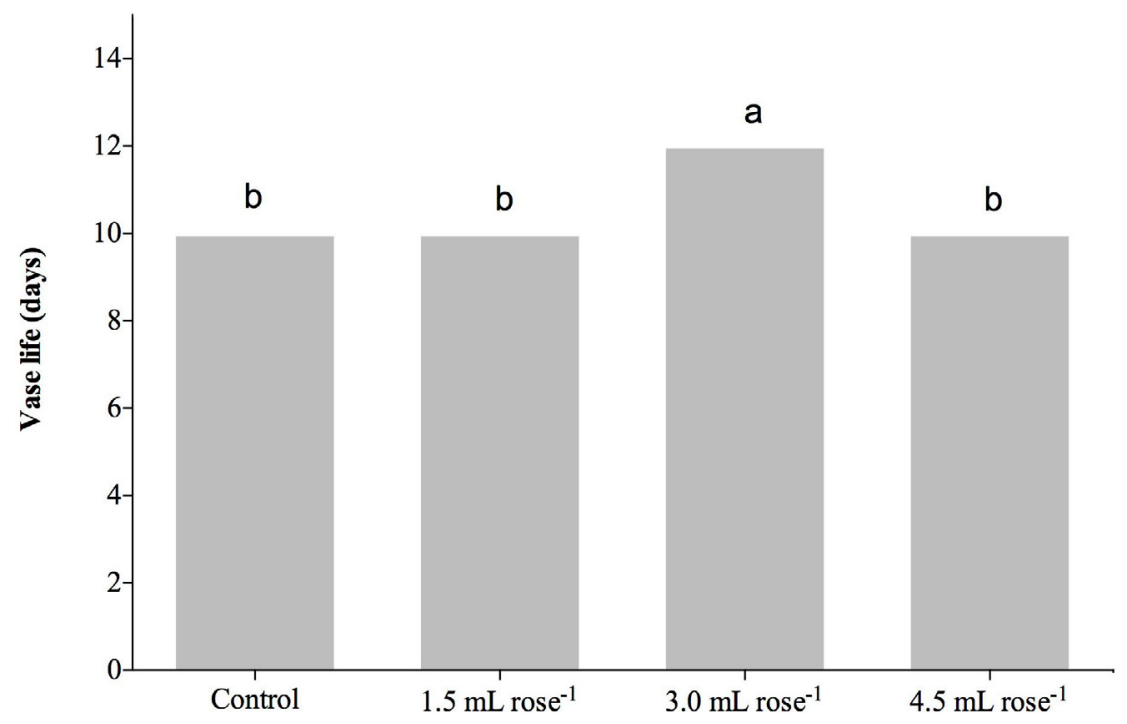

Figure 2: Vase life of cut roses cv. Avalanche treated with hydroxypropyl methylcellulose (HPMC)/Beewax (BW)based coating stored at $20^{\circ} \mathrm{C}$ and $70-80 \% \mathrm{RU}$.

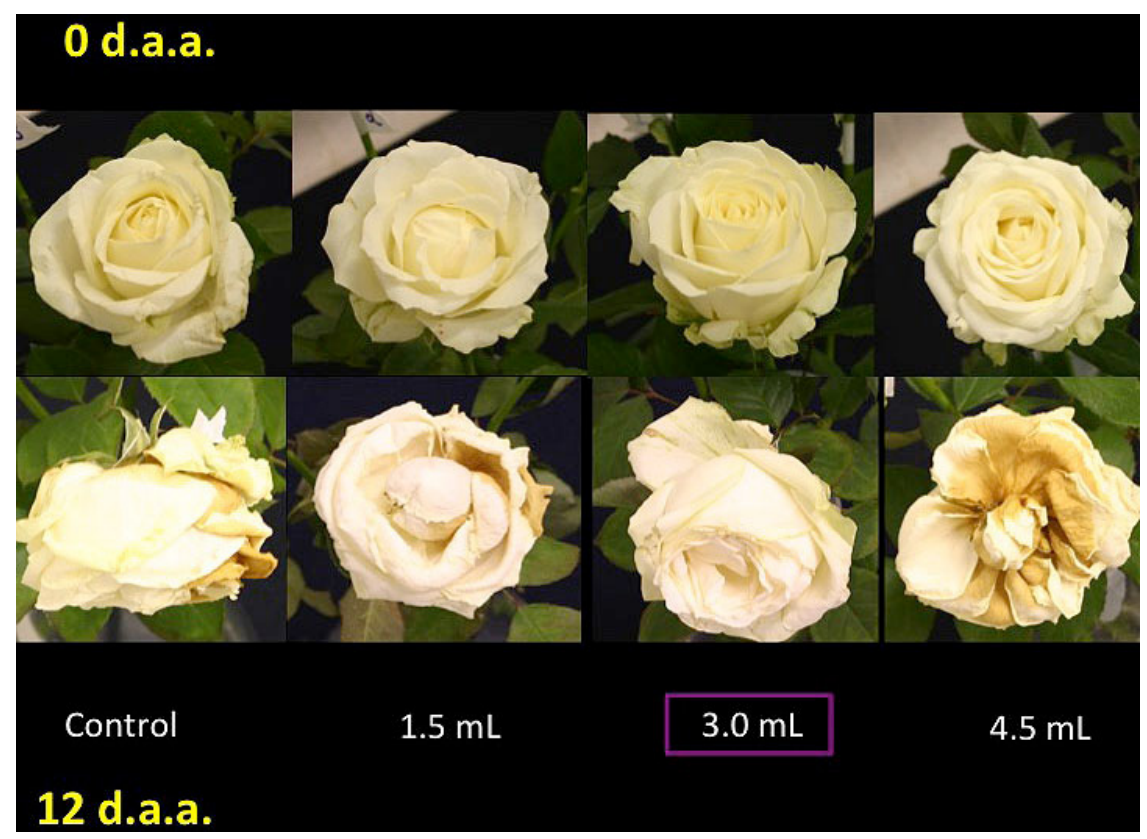

Figure 3: Cut roses cv. Avalanche treated with hydroxypropyl methylcellulose (HPMC)/Beeswax (BW)-based coating stored at $20^{\circ} \mathrm{C}$ and $70-80 \% \mathrm{RU}$, at the time 0 and after 12 days after application (d.a.a).

These results show that coatings based on HPMC and beeswax likely formed a barrier to water vapor on the surface of rose petals, decreasing transpiration and maintaining tissue turgor.

Preserving water inside the stem is essential for the maintenance of physiological processes that ensure the quality and longevity of the flowers during transportation and storage.

The regulation of water loss is mostly under physiological control (stomata), while water absorption is primarily a physical process in cut flowers (Fanourakis et al., 2012). A suitable stomatal response to different 
closing stimuli (dark and low water potential) limits the net loss of water from cut flowers, and consequently delays wilting (van Doorn, Schurer; White, 1989; Bleeksma and van Doorn, 2003). The coating applied to the petals of the roses minimized transpiration, which completely or partially covered the stomata, and micropores, becoming a semipermeable barrier to gas exchange (Oliveira et al., 2018; Assis; Britto, 2014). According to Oliveira et al. (2018), beeswax acts hydrophobically and limits the exchange of water vapor, which reduces the loss of mass of the plant.

In addition, fresh weight loss is one of the most important physiological changes of cut flowers (Saeed et al., 2016) after harvest, which is commonly followed by reduced shelf life and loss of quality. The loss of fresh mass is associated with water loss, resulting in premature wilting of flowers and leaves, as well as bent-neck (Torre; Fjeld; Gislerød, 2001; Mortensen; Gislerød, 2005). These symptoms reduce the visual quality of the plants, hindering or even preventing their sale. Turgidity of plants is directly associated with the maintenance of water inside the cells to ensure their functioning.

Postharvest surveys of roses indicate that lack of water is the most frequent cause reduced vase life in most of the cultivars studied. The second is the incidence of rot by the fungus Botrytis cynerea and physiological senescence (Fanourakis et al., 2012).

The most prominent symptoms of stress due to lack of water are loss of petal turgor (floral wilting), bent-neck, and wilted leaves. Such symptoms are usually associated with a negative water balance, when water demand (transpiration) exceeds water absorption (van Doorn, 2012).

Xylem occlusion may be related to blockage of the xylem vessels, resulting from the entry of air in cut stems (air emboli) or the accumulation of microorganisms in vascular system (van Doorn, 1999; Mattiuz et al., 2015).

Together, our results corroborate other studies with cut flowers, demonstrating that adequate water absorption is an important factor to maintain a favorable water balance, and promote the longevity of cut flowers (Ebrahimzadeh et al., 2008; Liu et al., 2009; Perik et al., 2012; Shabanian, et al., 2018).

The RWC is indicative of the water status of the plant (Nandane; Dave; Rao, 2017; Su et al., 2013). In our study, RWC increased in all treatments until the 3rd day of evaluation, which can be attributed to the hydration of the stems under good conditions of water supply, temperature $\left(20^{\circ} \mathrm{C}\right)$ and high relative humidity $(70-80 \%)$. Costa et al. (2017) also observed an increase in RWC in the first hours of storage in a study with gladioli, which was attributed to the good hydration of the stems. As can be observed over time, stems that received $3.0 \mathrm{~mL}$ of coating had the best RWC, whose barrier created by the coating on the surfaces of the petals, limits the loss of water and maintains the turgescence in the vegetal tissue.

The results obtained in this study corroborate with those obtained by Ahmad and Tahir (2016) where the MSI decreased over time in a study performed with Iris versicolor, reaching values below $50 \%$ for MSI by the end of storage time. In our study, the control treatment also had an MSI within $50 \%$ on the 9 th day of evaluation, indicating an advanced state of senescence and severe deterioration of the membrane.

Floral senescence results from the loss of membrane integrity caused by changes in the protein and lipid content of the membrane. The reduction in membrane phospholipid content is one of the main causes of loss of membrane integrity (Ahmad; Tahir, 2016). Petal wilting is indicative of loss of cellular membranes integrity, and loss of pigments, nutrients and electrolytes (Rubinstein, 2000).

\section{CONCLUSIONS}

Our results are promising for the application for natural coatings in cut flowers to prolong vase life. The coating with hydroxypropyl methylcellulose and beeswax sprayed at $3.0 \mathrm{~mL}$ per rose extended vase life in 2 days and improved the physiological status of the roses. The coating was able to delay the deterioration of the cell membrane affected by plant senescence. Moreover, the coating application is easy and safe for the environment and consumer.

\section{REFERENCES}

AHMAD, S. S.; TAHIR, I. Increased oxidative stress, lipid peroxidation and protein degradation trigger senescence in Iris versicolor L. flowers. Physiology and Molecular Biology of Plants, 22(4):507-514, 2016.

ASSIS, O. B. G.; BRITTO, D. Revisão: Coberturas comestíveis protetoras em frutas: Fundamentos e aplicações. Brazilian Journal Food Technology, 17(2):87-97, 2014.

BLEEKSMA, H. C.; VAN DOORN W. G. Embolism in rose stems as a result of vascular occlusion by bacteria. Postharvest Biology and Technology, 29(3):334-340, 2003.

CEAGESP. Companhia de Entrepostos e Armazéns Gerais de São Paulo. Available in: <http://www.ceagesp.gov.br/ guia-ceagesp/rosa/>. Access in: January, 25, 2019. 
COSTA, L. C. et al. Vase life and rehydration capacity of drystored gladiolus flowers at low temperature. Ciência Rural, 47(2): e20160139, 2017.

DEHGHANNYA, J. et al. Osmotic dehydration of apple slices with carboxy-methyl cellulose coating. Drying Technology, 24(1):45-50, 2010.

DOI, M.; HU, Y.; IMANISHI, H. Water relations of cut roses as influenced by vapor pressure deficits and temperatures. Engei Gakkai Zasshi, 69(5):584-589, 2000.

EBRAHIMZADEH, A. et al. Post-harvest physiology of cut carnation flowers. Fresh Produce, 2(2):56-71, 2008.

FAGUNDES, C. et al. Effect of antifungal hydroxypropyl methylcellulose-beeswax edible coatings on gray mold development and quality attributes of cold-stored cherry tomato fruit. Postharvest Biology and Technology, 92:1-8, 2014.

FAGUNDES, C. et al. Antifungal activity of food additives in vitro and as ingredients of hydroxypropyl methylcelluloselipid edible coatings against Botrytis cinerea and Alternaria alternata on cherry tomato fruit. International Journal of Food Microbiology, 166(3):391-398, 2013.

FANOURAKIS, D. et al. Postharvest water relations in cut rose cultivars with contrasting sensitivity to high relative air humidity during growth. Postharvest Biology and Technology, 64(1):64-73, 2012.

IMSABAI W. et al. Petal blackening and lack of bud opening in cut lotus flowers (Nelumbo nucifera): Role of adverse water relations. Postharvest Biology and Technology, 79:32-38, 2013.

KRAMER, P. J. Water Relations of Plants. New York Academic Press, New York, 1983. 483p.

LIU, J. et al. Nano-silver pulse treatments inhibit stem-end bacteria on cut gerbera cv: Ruikou flowers. Postharvest Biology and Technology, 54(1):59-62, 2009.

MCGUIRE, R. G.; HALLMAN, G. J. Coating guavas with celluloseor carnauba-based emulsions interferes with postharvest ripening. HortScience, 30(2):294-295, 1995.

MATTIUZ, C. F. M. et al. Effectiveness of postharvest solutions for the conservation of cut Oncidium varicosum (orchidaceae) inflorescences. Ciência e Agrotecnologia, 39(4):315-322, 2015.

MANSOURI, H. Salicylic acid and sodium nitroprusside improve postharvest life of chrysanthemums. Scientia Horticulturae, 145:29-33, 2012.
MORTENSEN, L. M.; GISLERØD, H. R. Effect of air humidity variation on powdery mildew and keeping quality of cut roses. Scientia Horticulturae, 104(1):49-55, 2005.

NANDANE, A. S.; DAVE, R. K.; RAO, T. V. R. Optimization of edible coating formulations for improving postharvest quality and shelf life of pear fruit using response surface methodology. Journal of Food Science and Technology, 54(1):1-8, 2017.

NAVARRO-TARAZAGA, M. L.; MASSA, A.; PÉREZ-GAGO, M. B. Effect of beeswax content on hydroxypropyl methylcellulosebased edible film properties and postharvest quality of coated plums (cv. Angeleno). Food Science and Technology, 44(10):2328-2334, 2011.

NOWAK, J.; RUDNICKI, R. M. Postharvest handling and storageof cut flowers, florist greens and potted plants. Timber Press, Portland. 1990. 210p.

OLIVEIRA, V. R. L. et al. Use of biopolymeric coating hydrophobized with beeswax in post-harvest conservation of guavas. Food Chemistry, 259:55-64, 2018.

PERIK, R. R. J. et al. Bending in cut Gerbera jamesonii flowers relates to adverse water relations and lack of stem sclerenchyma development, not to expansion of the stem central cavity or stem elongation. Postharvest Biology and Technology, 74:11-18, 2012.

PÉREZ-GAGO, M. B.; ROJAS, C.; DEL RIO, M. A. Effect of lipid type and amount of edible hydroxypropyl methylcellulose-lipid composite coatings used to protect postharvest quality of mandarins CV. fortune. Journal of Food Science, 67(8):29032910, 2002.

RANI, P.; SINGH, N. Senescence and postharvest studies of cut flowers: A critical review. Journal of Tropical Agriculture and Science, 32(2):159-201, 2014.

RUBINSTEIN, B. Regulation of cell death in flower petals. Plant Molecular Biology, 44(3): 303-318, 2000.

SAEED, T. et al. Antioxidative activities and qualitative changes in gladiolus cut flowers in response to salicylic acid application. Scientia Horticulturae, 210:236-241, 2016.

SANDERSON, G. R. Polysaccharides in Foods. Food Technology, 35(1):50-56, 1981.

SENGUPTA, S.; MAJUMDERA. L. Insight into the salt tolerance factors of a wild halophytic rice, Porteresia coarctata: A physiological and proteomic approach. Planta, 229(4):911-929, 2009.

SHABANIAN, S. et al. Physiological and biochemical modifications by postharvest treatment with sodium nitroprusside extend vase life of cut flowers of two gerbera cultivars. Postharvest Biology and Technology, 137:1-8, 2018. 
SINGH, A.; KUMAR, P. Effects of plant growth regulators and sucrose on postharvest physiology, membrane stability and vase life of cut spikes of gladiolus. Plant Growth Regulation, 55: 221-229, 2008.

SU, Z. et al. Flower development under drought stress: Morphological and transcriptomic analyses reveal acute responses and long-term acclimation in Arabidopsis. The Plant Cell, 25(10):3785-3807, 2013.

TORRE, S.; FJELD, T.; GISLERØD, H. R. Effects of air humidity and $\mathrm{K} / \mathrm{Ca}$ ratio in the nutrient supply on growth and postharvest characteristics of cut roses. Scientia Horticulturae, 90(3):291-304, 2001.
VAN DOORN, W. G. Water relations of cut flowers: An update. Horticultural reviews, 40:55-106, 2012.

VAN DOORN, W. G.; REID, M. S. Vascular occlusion in stems of cut rose flowers exposed to air: Role of xylem anatomy and rates of transpiration. Physiology of Plants, 93:624-629, 1995.

VAN DOORN W. G. Vascular occlusion in cut flowers. I. General principles and recent advances. Acta Horticulturae, 482:59-64, 1999.

VAN DOORN, W. G.; SCHURER, K.; DE WITTE, Y. Role of endogenous bacteria in vascular blockage of cut rose flowers. Journal of Plant Physiology, 134:375-381, 1989. 